\title{
de Quervain 病における超音波診断
}

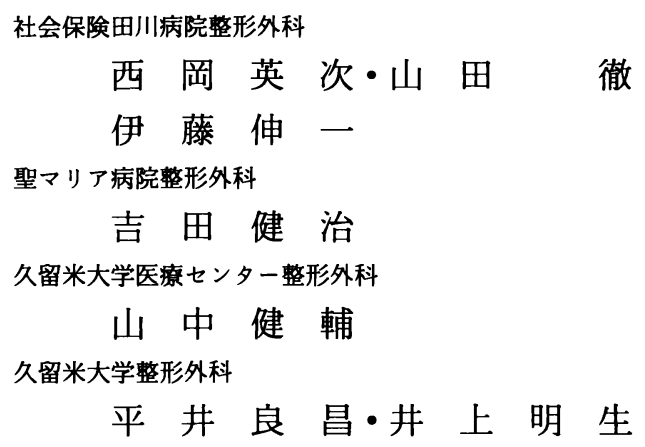

\section{Ultrasound Examination of de Quervain Disease}

Eiji Nishioka, Tetsu Yamada, and Shinichi Ito

Social Insurance Tagawa Hospital

Kenji Yoshida

Department of Orthopaedic Surgery, St. Mary's Hospital

Kensuke Yamanaka

Department of Orthopaedic Surgery, Kurume University Medical Center

\section{Yoshimasa Hirai, and Akio Inoue}

Department of Orthopaedic Surgery, School of Medicine, Kurume University

Ten cases of de Quervain disease were examined by ultrasound. Three were treated with surgical method. Ultrasound examinations were performed with $7.5 \mathrm{MHz}$ transducers. We classified the patterns of the septum in the first extensor compartment of the wrist into three groups, complete type, incomplete type, and no septum type. According to this classification, seven cases were of the incomplete type, and the other three cases were of no septum type. Three cases treated with the operative method were of the incomplete type. Ultrasound examination seems to be useful for the diagnosis of the Quervain disease.

Key words : de Quervain disease (ドゥケルバン病), Ultrasound examination (超音波診断), Septum (隔壁)

\section{はじめに}

de Quervain 病はその臨床症状により診断は比較 的容易であるが, 画像診断は今まであまり行われてい ない，今回我々は超音波にて de Quervain 病の病態
の把握が可能かどうか，また隔壁の状態の把握にも有 効であるかどうかについて検討した。

\section{対象及び方法}

外来診察で de Quervain 病と診断した 10 例の患者 
について検討した. 年齢は 29 歳〜80 歳, 平均 56 歳 である. 患部へのステロイド注射にても軽快しない 3 例のものに手術を行った.

超音波の走查は健側の長軸・短軸像, 患側の長軸・ 短軸像を検討した。 なお患側の短軸像は, 隔壁の状態 を把握するために橈骨茎状突起の遠位部, 橈骨茎状突 起上, 橈骨茎状突起の近位部にて検討した.

\section{結果}

長軸像では腱の肥厚像がみられるもの（図 2 B) や, 腱の高エコー像とその周井の低エコー像（図 1 B) が 特徵的なものがあった. 短軸像では隔壁のみられない あの 7 例, 不完全隔壁と思われたもの 3 例であった. 完全隔壁と思われるものは今回の調查からは確認でき なかった。隔壁は APL, EPB 間の低エコー像で確認 できた，隔壁のみられないあのでは APL, EPBが一 塊の高エコー像で確認できたが, APL, EPB の区別 はできなかった（図 $2 \mathrm{C}$ ).

手術例の 3 症例はいずれも術前にエコー像で不完全 隔壁と診断した（図1C) が, 手術所見でも隔壁が橈 骨茎状突起部より遠位に存在し (図 1 D). これを切 離した. APL は 2 本のものが 2 症例, 3 本のものが 1 症例であった，EPB は全例とも 1 本であった。 ま た 1 症例では, 腱鞘上の 2 カ所にガングリオンを認め た.

\section{考察}

de Quervain 病の発症原因として, 長母指外転筋 腱, 短母指伸筋腱間の隔壁の存在が指摘されている. 堀内ら ${ }^{2)}$ はさらに伸筋腱鞘第一区画内の隔壁について, 隔壁のないものを正常型, 隔壁のあるもののうち隔壁 が完全なものを完全隔壁型, 隔壁が不完全なものを不 完全隔壁型と分類している.

不完全隔壁の開始部について Jackson ら ${ }^{3)}$ は伸筋 腱鞘第一区画の遠位 $1 / 3 \sim 1 / 2$ としている. 小倉ら ${ }^{4)}$ は, 橈骨茎状突起遠位端より $10 \mathrm{~mm}$ 末満のものとし ている. またBruce ら は隔壁について橈骨茎状突 起部より近位へ $0.5 \sim 2 \mathrm{~cm}$ としている.このため我々 は短軸走查を橈骨茎状突起遠位端部, 橈骨茎状突起上, 橈骨茎状突起近位端部で行い, 完全隔壁と不完全隔壁 の区別を試みた.

不完全隔壁のものは橈骨茎状突起遠位端部, 橈骨茎 状突起部で隔壁が確認できたが, 橈骨茎状突起近位端

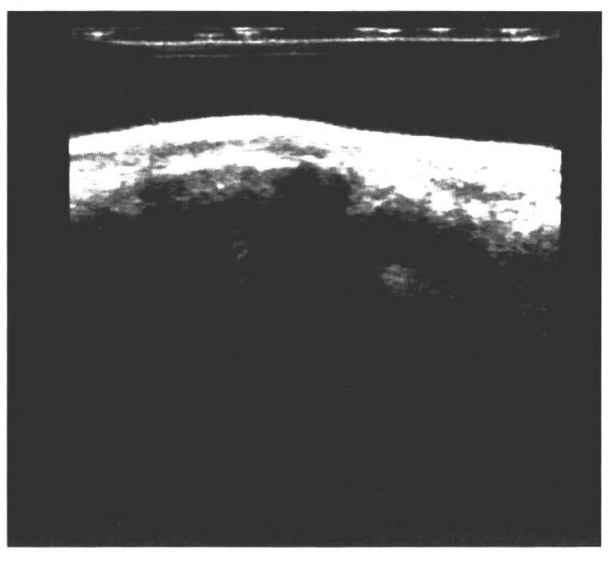

A

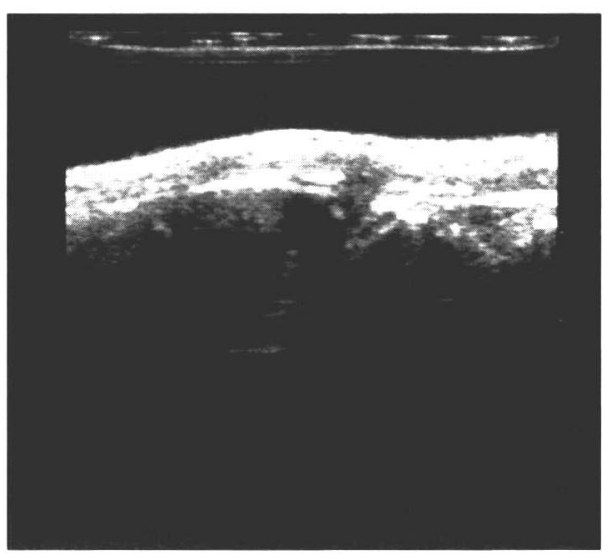

B

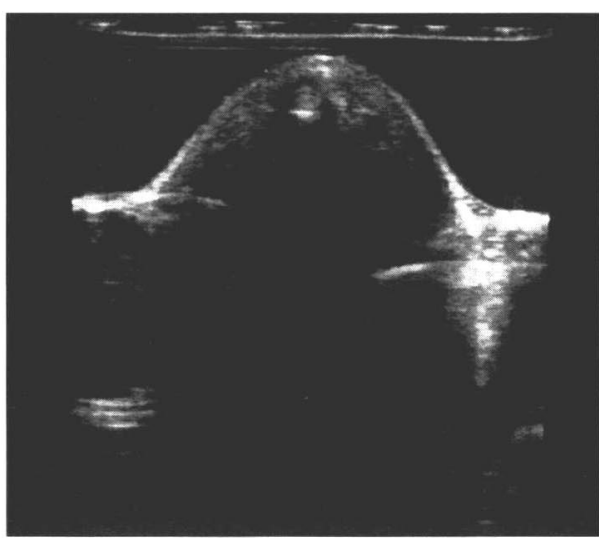

C a 


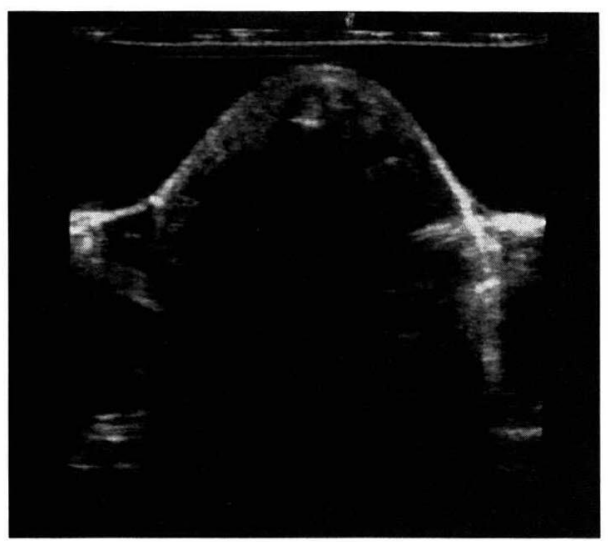

C b

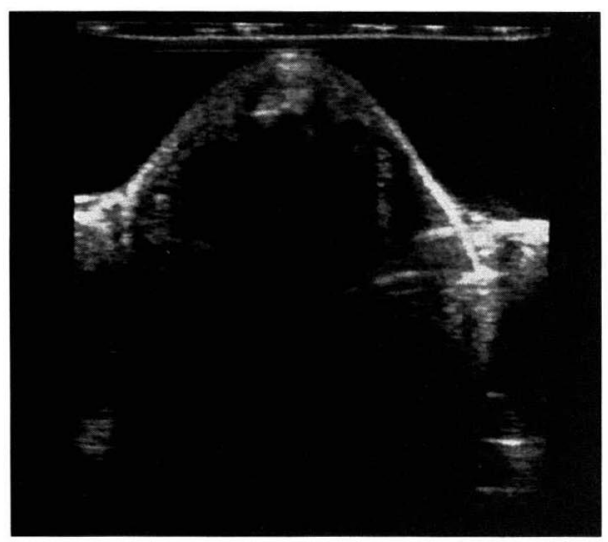

C c

部では確認できなかった．また今回完全隔壁のものは 確認することができなかったが, 橈骨茎状突起近位端 部でも描出できるのではないかと推測される.

手術を行った 3 例では全例不完全隔壁を認め, EPB は絞扼されており, 隔壁を切離することにより症状の 改善をみている. 術前に隔壁の存在をエコーにて確認 しておくことは, 治療の方針決定にも有効な検查法で はないかと思われる.

\section{ま と め}

1. de Quervain 病患者 10 例に超音波検査を施行 した.

2. 短軸像で隔壁のみられないもの 7 例, 不完全隔 壁と思われたあの 3 例であった。 手術例はすべて不完

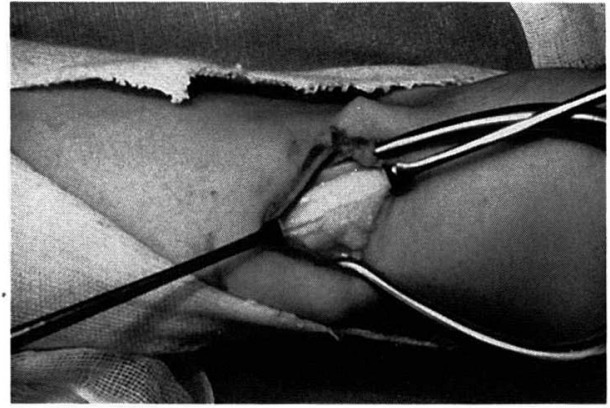

D

図 129 歳男性（右）

A. 健側 (長軸)

B. 患側 (長軸)

腱の高エコー像とその周囲の低エコー像が 認められる.

C. 短軸像

橈骨茎状突起遠位部, 橈骨茎状突起上の短 軸走查で EPB，APL 間に低エコー像の隔 壁が認められる.

a 橈骨茎状突起遠位部

b 橈骨茎状突起上

c 橈骨茎状突起近位部

D. 術中

橈骨茥状突起より遠位に不完全隔壁を認め る.

全隔壁であった.

3. 隔壁の把握に超音波検査は有効と思われる.

\section{参 考 文 献}

1) Bruce M. Leslie, William B. Ericson, Jr., James R. Morehead : Incidence of a septum within the first dorsal compartment of the wrist. J. Hand Surg., 15A-1 : 88-91, 1990.

2）堀内行雄, 伊藤恵康, 根本哲夫ら: de Quervain 病手 術例の検討, 整形外科, $40: 199-203,1989$.

3) Jackson W.T., Viegas S. G., Coon T. M., et al : Anatomical variations in the first extensor compartment of the wrist. J. Bone Joint Surg., 68A : 923-926, 1986.

4）小倉 丘, 赤堀 治 : 伸筋腱第一区画の解剖所見につ いて, 日手会誌, 6 （3）：473-476, 1989. 


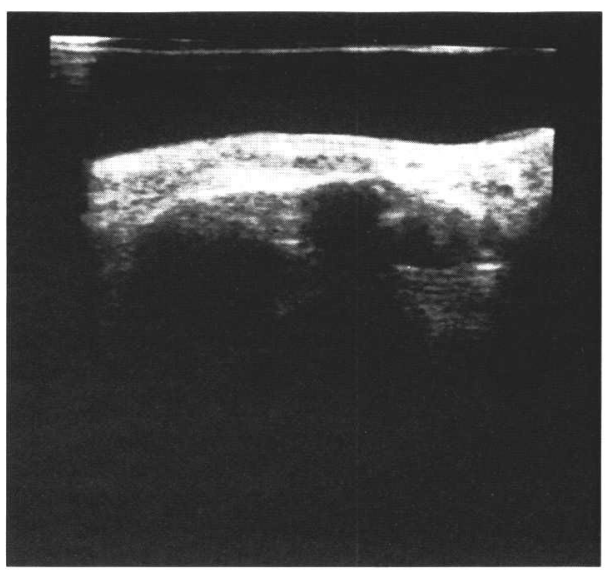

A

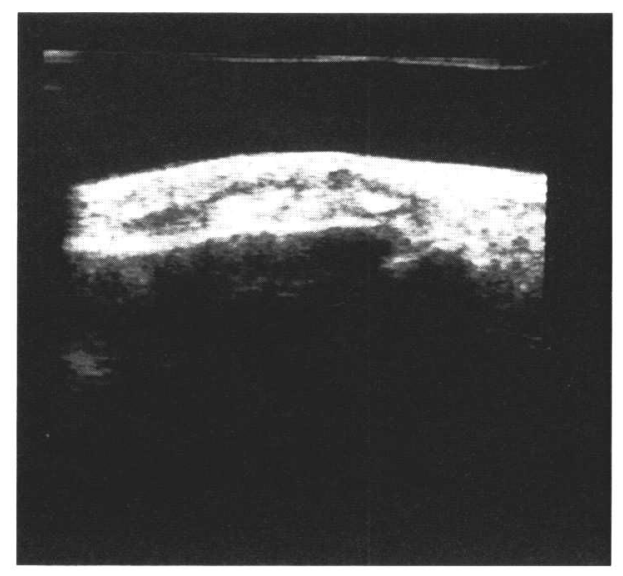

B

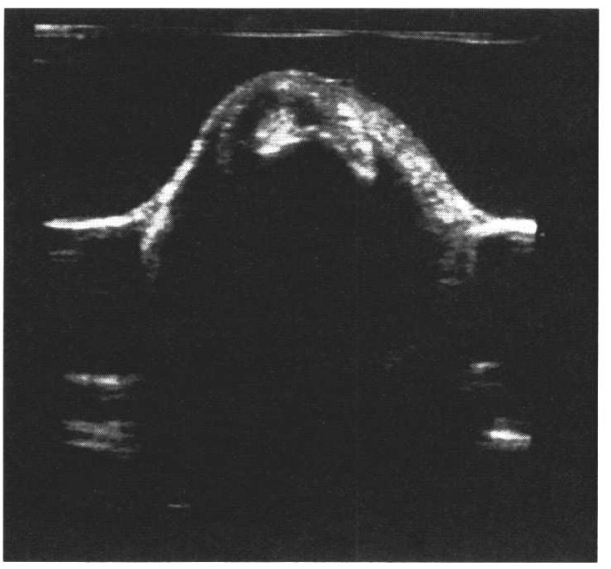

C a

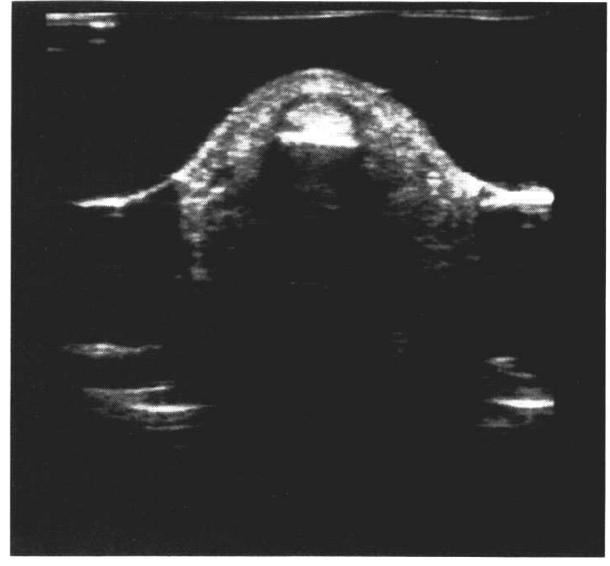

C b

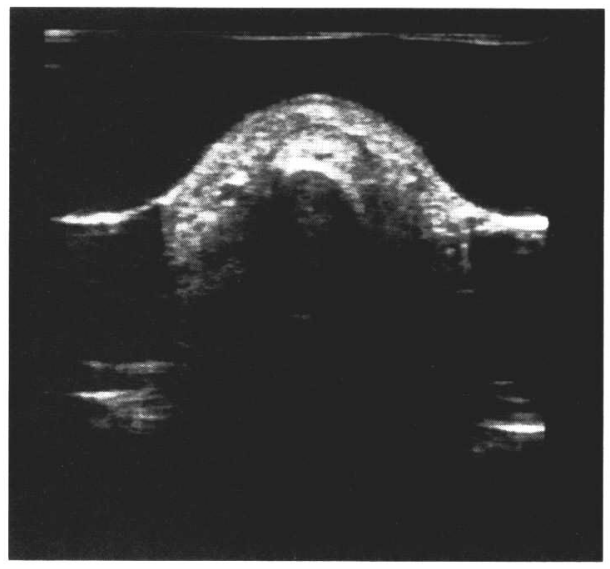

C c

図 271 歳女性（左）
A. 健側 (長軸)
B. 患側 (長軸) 腱の肥厚像を認める
C. 短軸像
腱の高エコー像が認められるが, APL, EPB の区別はできない.
a 橈骨茎状突起遠位部
b 橈骨茎状突起上
c 橈骨茥状突起近位部 